\title{
DEVELOPMENT OF MOSQUITOFISH \\ (GAMBUSIA AFFINIS HOLBROOKI) POPULATIONS IN LENTIC MESOCOSMS. PERSPECTIVES FOR ECOTOXICOLOGICAL STUDIES.
}

\author{
V. DRÈZE, O. GAULAY and G. MONOD
}

Équipe Écotoxicologie Aquatique, INRA, SCRIBE, IFR 43, Campus de Beaulieu, 35042 Rennes Cedex, France.

\begin{abstract}
In the perspective of ecotoxicological assays in mesocosms, the development of mosquitofish populations (Gambusia affinis holbrookl) has been assessed. The objective was to evaluate the ability of fish to reproduce in these experimental ponds under the climatic conditions of Brittany, and to see if population size and individual criteria were related to the number of adults initially introduced. Six mesocosms $(3.2 \mathrm{~m}$ diameter and $0.7 \mathrm{~m}$ water depth) similarly designed received sexually mature mosquitofish at the rate of 12 ( 6 females and 6 males), 6 ( 3 females and 3 males) and 2 ( 1 female and 1 male) in June 1996. Each assay was duplicated. In December 1996, the entire populations were collected and the weight, size and sex of the individuals were noted. Length-frequency distributions were relatively similar between mesocosms and the different mode groups showed that the reproductive activity occurred until the beginning of fall. The produced biomass (from 4.1 to $38.3 \mathrm{~g}$ ) and number of fish collected (from 26 to 301) were statistically correlated to the number of pairs initially introduced. This study provides interesting perspectives for ecotoxicological investigations in which the effects of pollutants on mosquitofish would be assessed at the population level.
\end{abstract}

Key-words : fish, Gambusia affinis holbrooki, mesocosm, population, reproduction.

\section{DÉVELOPPEMENT DE POPULATIONS DE GAMBUSIE (GAMBUSIA AFFINIS HOLBROOKI DANS DES MÉSOCOSMES LENTIQUES. PERSPECTIVES POUR DES ÉTUDES ÉCOTOXICOLOGIQUES.}

\section{RÉSUMÉ}

Dans la perspective d'études écotoxicologiques en mésocosmes, le potentiel de développement de populations de gambusie (Gambusia affinis holbrooki) a été évalué. L'objectif était de savoir si la gambusie se reproduisait dans ces systèmes expérimentaux soumis aux conditions climatiques de la Bretagne, et si l'effectif final et la biomasse des populations étaient proportionnels au nombre de géniteurs initialement introduits. Six mésocosmes $(3,2 \mathrm{~m}$ de diamètre et $0,7 \mathrm{~m}$ de hauteur d'eau) constitués de façon identique ont reçu en juin 1996 des géniteurs de gambusie, à raison de 12 (6 femelles et 6 mâles), 6 ( 3 femelles et 3 mâles) et 2 ( 1 femelle et 1 mâle) individus par mésocosme. Chaque essai a été réalisé en duplicat. En décembre 1996, les populations ont été 
intégralement récupérées. Le poids, la longueur et le sexe des individus ont alors été déterminés. La distribution des longueurs des individus est relativement similaire d'un mésocosme à l'autre et fait apparaître plusieurs modes qui démontrent une activité reproductive de la gambusie s'étendant jusqu'au début de l'automne. Par ailleurs, la biomasse produite (de $4,1 \mathrm{~g}$ à $38,3 \mathrm{~g}$ ) et le nombre d'individus récoltés (de 26 à 301) sont statistiquement corrélés au nombre de géniteurs initialement introduits. Ces résultats ouvrent des perspectives vis-à-vis d'études écotoxicologiques futures dans lesquelles les traductions populationnelles des effets de polluants sur la reproduction de la gambusie seraient recherchées.

\author{
Mots-clés : poisson, Gambusia affinis holbrooki, mésocosme, population, \\ reproduction.
}

\title{
INTRODUCTION
}

Ecotoxicological studies can be carried out at different levels of biological organization depending on the objectives. While the molecular and biochemical levels may be relevant to investigate early effects of pollutants and to characterize biomarkers (MCCARTHY and SHUGART, 1990), investigations at the population level are more appropriate to assess long-term consequences of exposure to chemicals. In fish, experimental studies have mainly focused on lower levels of biological organization ( $\leq$ individual).

The number of ecotoxicological studies in reconstituted ecosystems (mesocosms), especially lentic, have been increasing during the last decade but a few of them have included fish for investigation at the population level (GIDDINGS et al., 1984 ; JOHNSON, 1976 ; KENNEDY et al., 1994 ; MULVEY et al., 1995). More recently, a particular attention has been devoted to design mesocosms of limited size in order to reduce the cost of the experiments, especially in a regulatory prospect, and to reduce the amount of chemicals to be handled. In spite of reduced size, self-sustainability should be preserved in reconstituted ecosystems dedicated to long-term ecotoxicological studies. However, self-sustainability of such ecosystems may be affected by large fish (e.g. bluegill sunfish, Lepomis macrochirus), and consequently trophic resources may act as a limiting factor for the development of fish populations (HILL et al., 1994). Furthermore, for growing populations of large fish species, predation may dramatically affect lower trophic levels, especially invertebrates, thus impeding ecotoxicological studies on these biological compartments (MORRIS et al., 1994).

The use of small fish may allow long-term investigations at the population level without a severe impact on the self-sustainability of artificial ecosystems. This was recently supported by results showing that fathead minnow (Pimephales promelas) could reproduce in $17-\mathrm{m}^{3}$ mesocosms without altering dramatically the other components of the ecosystems (SHAW et al., 1995). Mosquitofish (Poeciliidae family) display a number of interesting features for ecotoxicological investigations in various experimental contexts including mesocosms (MULLA et al., 1979 ; for review on Poeciliidae and particularly the Gambusia genus, see MEFFE and SNELSON, 1989). Mosquitofish originated from the south-eastern part of the USA but have been widely spread out into many tropical and temperate regions of the world for mosquito population control programmes. In France, mosquitofish were successfully introduced in both the south-eastern (along the Mediterranean coast) and western areas. Mosquitofish typically inhabit small, shallow bodies of water which can be reconstituted in mesocosms. Sexual dimorphism is easily 
visible in adults. The size of females is less than $60 \mathrm{~mm}$ whereas that of males is less than $35 \mathrm{~mm}$. Furthermore, the male phenotype is characterized by a modified anal fin, the gonopodium, and pelvic suspension which form an intromittent organ. After intrafollicular development, females give birth to competent fry (CONSTANTZ, 1989). In temperate areas, reproduction takes place during summer. Female sexual cycle is relatively short (about 1 month), so that breeding can occur several times a year and population development can be followed on a relatively short-time scale. Several studies have dealt with the effects of chemicals on mosquitofish, mostly at the individual level and especially with regard to the impact on secondary sexual characters (DRYSDALE and BORTONE, 1989 ; HOWELL et al., 1980 ; HUNSINGER et al., 1988 ; YAN, 1986).

In the present study, the development of mosquitofish populations was followed in lentic outdoor mesocosms over a 6 month-time period under the climatic conditions of Brittany. Different numbers of adult mosquitofish (sex-ratio 1:1) were introduced in the ponds in June 1996. The entire populations were collected in December 1996 and compared with regard to structure, number of individuals, and produced biomass. The main objective was to study the relationship between the number of adults initially introduced and the size of the population collected. Our study provides a conceptual framework for investigations of the direct impact of pollutants on reproductive capacity (fecundity and/or fertility) of mosquitofish through the assessment of responses at the population level.

\section{MATERIAL AND METHODS}

\section{Fish}

Mosquitofish were obtained from a pond located in the vicinity of the mesocosms during the fall of 1995 and held in the laboratory at $25^{\circ} \mathrm{C}$ under natural photoperiod. After observation of the bones of the gonopodium, fish were identified as Gambusia affinis holbrooki (eastern mosquitofish) (LLOYD and TOMASOV, 1985). During breeding, females with prominent black ventral mark were isolated for parturition. New-born fish were collected and stocked.

\section{Mesocosm design}

The mesocosms are located on the campus of the École Nationale Superieure $d^{\prime}$ Agronomie in Rennes (Brittany, France ; $48^{\circ} \mathrm{N} / 1.7^{\circ} \mathrm{W}$ ). They consist of circular metal tanks ( $3.2 \mathrm{~m}$ diameter ; $1.2 \mathrm{~m}$ height) buried in the ground on a quarter of their height. The inner face of the wall is covered with a thick liner. Each pond can be emptied and the entire water content and organisms collected using underground wells.

In March 1996, the ponds were lined with polyethylene film (0.8 $\mathrm{mm}$ thick), as for experiments involving pollutants, and sediments were introduced as a uniform layer of approximately $7 \mathrm{~cm}$ thick. Sediments were collected in a natural lake nearby the mesocosm experimental site. The mesocosms were filled with tap water so that the final level was $70 \mathrm{~cm}$ from the bottom (approximately $63 \mathrm{~cm}$ water depth). In April 1996, plankton and macrophytes were introduced into the mesocosms. Plankton was sampled in a large pond next to the experimental site. Macrophytes, Typha latifolia and Ceratophyllum submersum, were collected in surrounding natural pond. Bulrush shoots were rooted in polyethylene containers which were deposited onto the sediments in the western part of the ponds. $C$. submersum was hung as a small bush in the opposite part. 


\section{Physico-chemical parameters and general biological observations}

The measurement of physico-chemical parameters started in May 1996. Water temperature was recorded continuously using Hotdog ${ }^{\circ}$ Module ID Elpro dataloggers (Elpro-Buchs AG, Switzerland). In each mesocosm, $\mathrm{pH}$ and dissolved oxygen concentration were recorded weekly using a $\mathrm{Hi} 9025 \mathrm{C} \mathrm{pH}$-meter (HANNA Instruments, Germany) and an OX 1320 oxymeter equipped with a CellOx 325 sensor (WTW, Germany), respectively. Water depth was measured weekly. Growth of macrophytes as well as fish behaviour were assessed through periodic visual observations.

\section{Introduction and collection of fish}

On June 27, 1996, 20 females (about $35 \mathrm{~mm}$ long) and 20 males (about $25 \mathrm{~mm}$ long) were isolated from the individuals born in the laboratory and acclimated progressively to $20^{\circ} \mathrm{C}$, the actual temperature of the water in the mesocosms. Fish were released in the ponds on June 28, 1996. The number of fish per mesocosm was 2 ( 1 male and 1 female), 6 ( 3 males and 3 females), and 12 ( 6 males and 6 females). Each assay was duplicated. In December 1996, macrophytes were removed and the mesocosms emptied. For each pond, the entire mosquitofish population was collected in the flushing water and by hand catching for the fish that remained onto the sediments.

\section{Fish population parameters and data processing}

At the end of the experiment, fish collected from each mesocosm were numbered. After anaesthesia in phenoxy-2-ethanol, fish were measured for total length (from the tip of the nose to the anterior border of the anal fin) and weighed for fresh weight. Sex was determined through observation of the anal fin for fish $>20 \mathrm{~mm}$. Fish $\leq 20 \mathrm{~mm}$ were sacrificed, and gonads were sampled, squashed (GUERRERO and SHELTON, 1974) and observed under microscope $(x 100)$ for the presence of ovocytes or spermatozeugmata.

In mosquitofish, as in other poeciliids, the growth rates of juveniles of both sexes are similar. After sexual maturity, the growth rate increases in females while decreasing dramatically in males (REZNICK and MILES, 1989). Length-frequency distributions were therefore analyzed for both juveniles and females and for males. The relationship between the number of stocked females and the size of the population (expressed as number of individuals or total biomass produced) was established through regression analysis. After logarithmic transformation, the relation between individual length $(L)$ and fresh weight $(W)$ was linear (data not shown), and can be written as $W=a * L^{b}$, where $a$ is the Condition Index $\left(a=W / L^{b}\right)$. For each mesocosm, sex-ratio was calculated for sexually differentiated fish and for juveniles, and compared to unity (Chi-square test). All the statistical analyses were performed using StatView 4.1 (Abacus Concepts Inc., Berkeley, CA).

\section{RESULTS}

\section{Physico-chemical conditions and general biological observations}

The physico-chemical parameters followed similar patterns in the different mesocosms. Water temperature was about $20^{\circ} \mathrm{C}$ when mosquitofish were introduced. It increased up to $30^{\circ} \mathrm{C}$ in August and decreased to $10^{\circ} \mathrm{C}$ in December. Water depth was about $60 \mathrm{~cm}$ at the time of mosquitofish introduction, then levelled off at $40 \mathrm{~cm}$ from 
mid-September. $\mathrm{pH}$ was about 10.0 from the introduction of mosquitofish to mid-July, then decreased continuously to about 7.0 at the end of the experiment. Dissolved oxygen concentrations showed tremendous daily variations with the lowest values (about $1.0 \mathrm{mg} / \mathrm{l}$ in August) at the end of the night and the highest values (about $15.0 \mathrm{mg} / \mathrm{l}$ in July) during the afternoon.

Bulrush developed very quickly whereas $C$. submersum could not develop due to competition with filamentous algae and more importantly with other plant species such as Zanichellia palustris and Alisma plantago-aquaticus. These species were accidentally introduced with sediments, and developed rapidly so that $C$. submersum disappeared. Nevertheless, macrophytes structured the ponds in two different areas : the T. latifolia-dominated part provided a shallow area whereas the opposite part, dominated by immersed plant species, received direct sunlight.

Qualitative observations and quantitative sampling of macroinvertebrates were made throughout the experimental period. A number of insect larvae, triclads (Dugesia sp.) and young freshwater snails (Physa $s p$.) were found on artificial substrates used as samplers, and emerging insects were collected for species distribution and abundance. Adults and larvae of water bugs (Gerris sp., Hydrometra sp., Corixa sp. and Notonecta sp.) and water beetles (Dytiscidae and Hydrophilidae) were frequently observed. Adult dragonflies (Libellulidae and Aeschnidae) and damselflies (Coenagrionidae and Lestidae) were seen actively hunting, mating and depositing eggs, and nymphal exuviae were frequently found on emerged parts of macrophytes (A. Jumel and L. Lagadic, personal communications).

\section{Observation of mosquitofish}

Visual observations of mosquitofish were performed in the mesocosms during the experiment. In one of the ponds stocked with 1 pair, only the female was sometimes visible and also was the only one found at the end of the experiment, suggesting that reproduction did not occur. Therefore, this mesocosm was not considered in subsequent analysis. Juveniles were seen in the mesocosms with the highest adult stocking in early July 1996. In summer and at the beginning of fall, adults and juveniles were observed mainly in the upper part of the water column and their density was much higher in areas receiving direct sunlight (with temperature up to $30^{\circ} \mathrm{C}$ in summer) and with high density of submersed macrophytes, than in shadow areas. No aggressiveness between individuals was observed. Grouping of individuals of similar size seemed to occur. In November and December, only few individuals were visible.

\section{Length-frequency distribution}

The length-frequency distributions of both females and juveniles combined and of males are presented in Figure 1. Similar patterns were observed between the mesocosms. The length of females varied between $21 \mathrm{~mm}$ and $57 \mathrm{~mm}$. Females stocked at the beginning of the experiment were typically the largest and were located in a well-differentiated peak comprised between $49 \mathrm{~mm}$ and $57 \mathrm{~mm}$ depending on the mesocosm. For both females and juveniles, histograms show that females occurred at 4 to 5 mode groups whereas juveniles occurred at 1 to 2 mode groups, except in the mesocosm stocked with 1 pair where only 2 well-separated peaks (one female group and one juvenile group) occurred in addition to the female stocked initially. In general, the groups corresponding to the smallest fish (immatures and youngest mature females) were more plentiful than the groups corresponding to the largest fish. The length of males exhibited gonopodium was comprised between 21 and $35 \mathrm{~mm}$, except one individual $(18 \mathrm{~mm})$ and appeared mainly as a bimodal group. 
$-1 \mathrm{M}-1 \mathrm{~F} \longrightarrow$
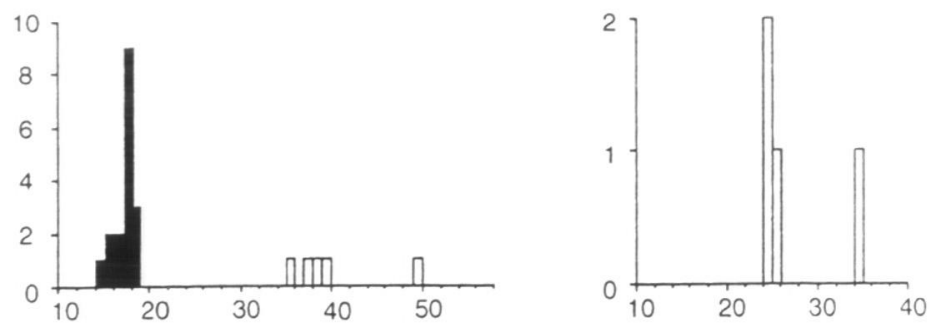

$-3 \mathrm{M}-3 \mathrm{~F} \longrightarrow$
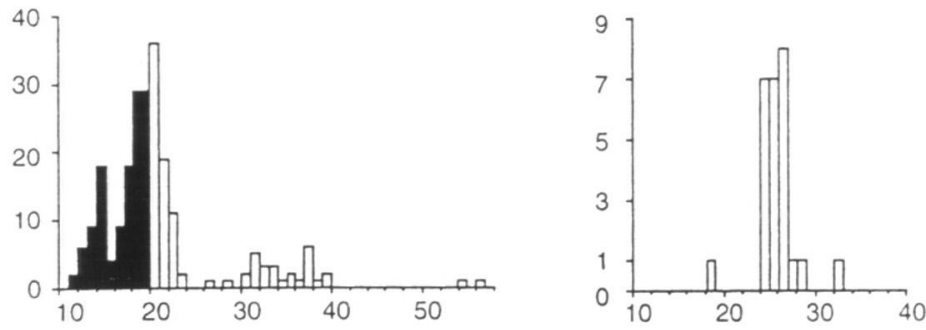

- $3 \mathrm{M}-3 \mathrm{~F}$
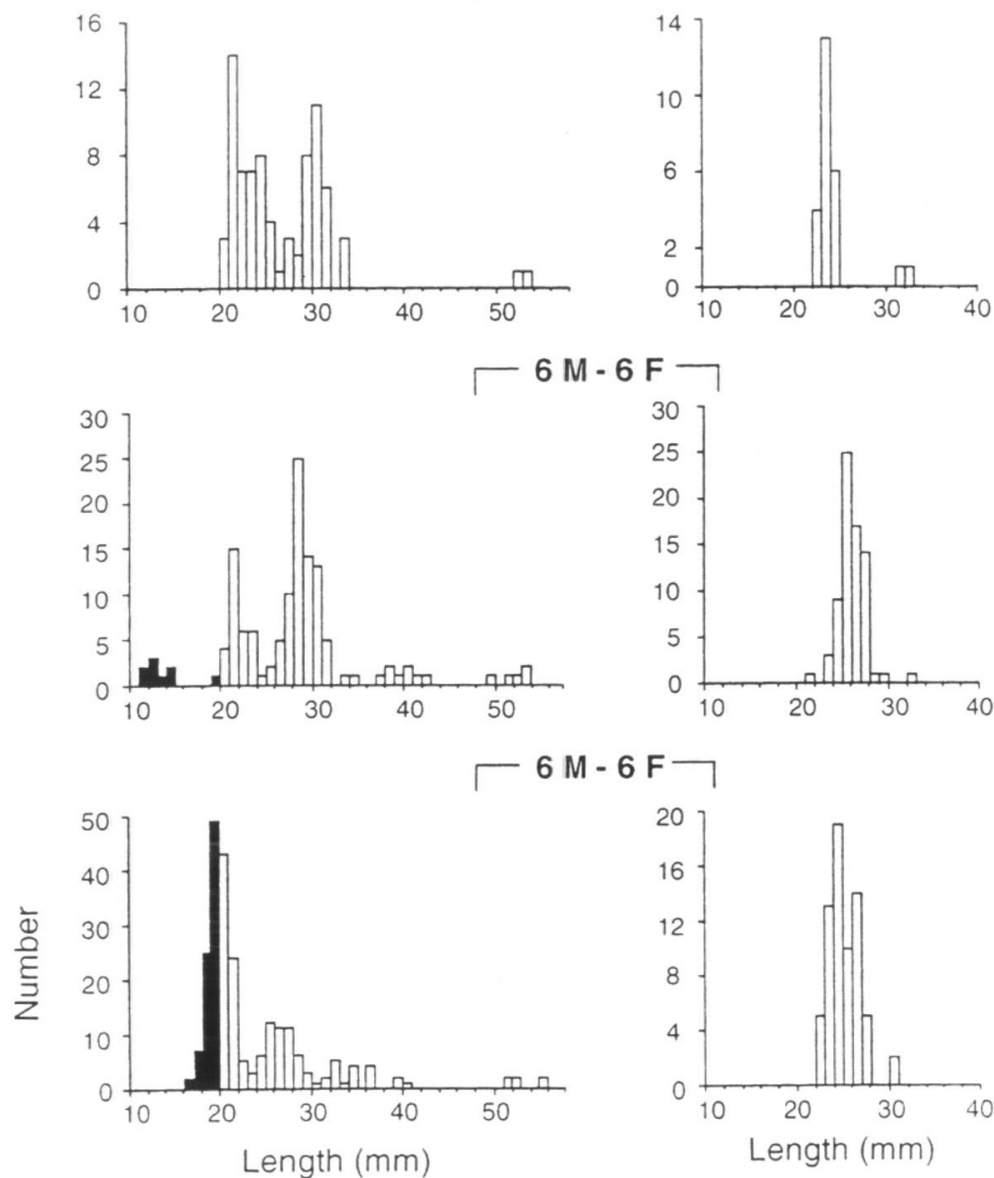

Figure 1

Length-frequency distribution of the individuals for the five mesocosms.

On the left part, size distributions of females (white bars) and juveniles (black bars). Rightmost bars represent the reproducing females initially stocked. On the right part, size distributions of the males. Note that different scales have been used for the $Y$-axis. $M$ : males ; $F$ : females. 


\section{Figure 1}

Histogrammes de distribution des tailles des individus pour les cinq mésocosmes.

Sur la partie gauche, distribution des tailles des femelles (barres blanches) et des juvéniles (barres noires). Les barres les plus à droite représentent les génitrices initialement introduites. Sur la partie droite, distribution des tailles des mâles. Différentes échelles ont été utilisées pour l'axe Y. M : mâles ; F : femelles.

\section{Fish biomass and number}

Produced biomass, represented by fresh weight of mosquitofish collected in December 1996, is presented in Figure 2. Produced biomass varied from $4.1 \mathrm{~g}$ (1 pair initially stocked) to $38.3 \mathrm{~g}$ (6 pairs). The value of the regression coefficient between the number of pairs initially introduced and the produced biomass was $0.97(p<0.001)$.

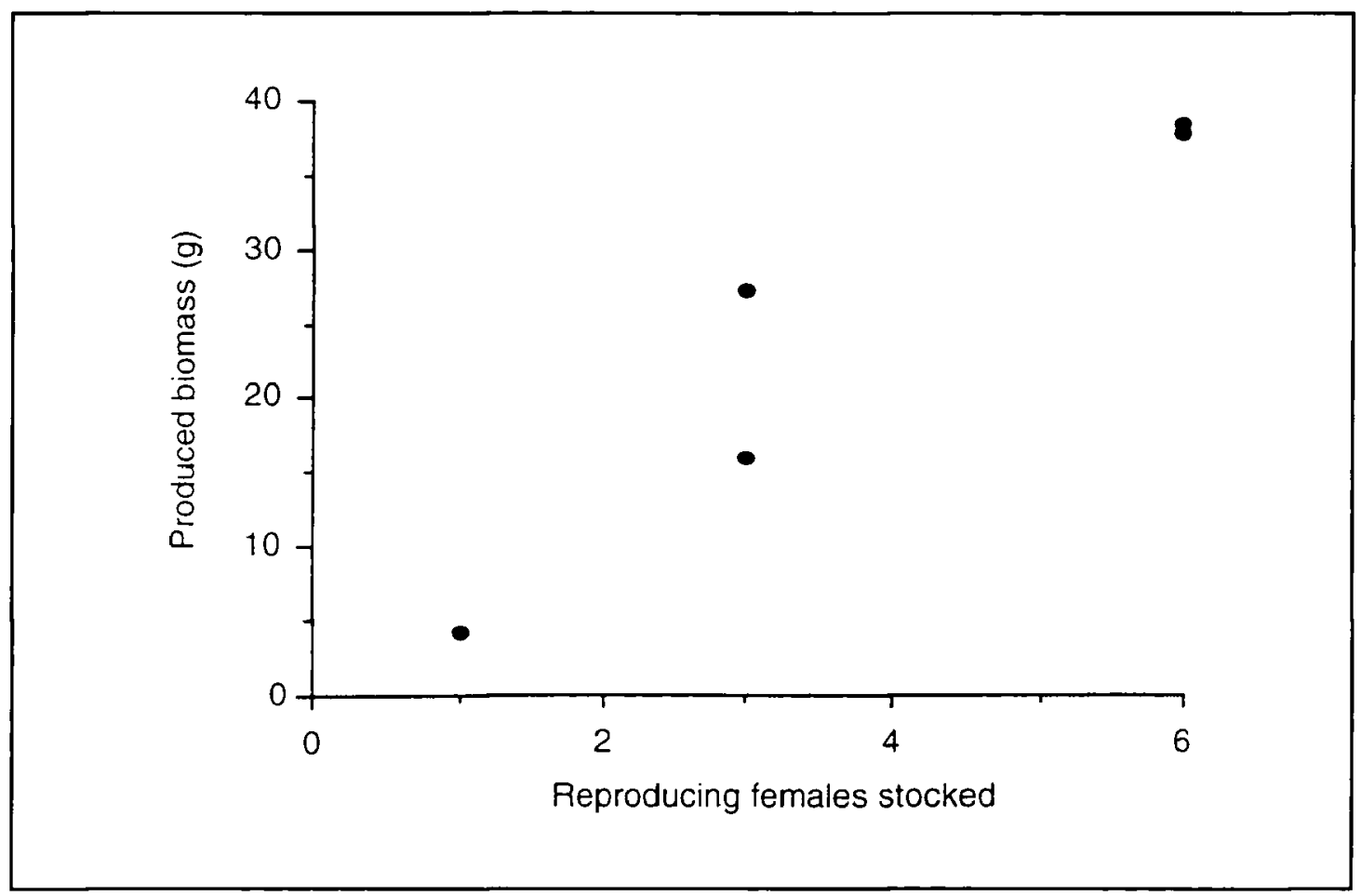

Figure 2

Relationship between the biomass of mosquitofish (fresh weight, $g$ ) at the end of the experiment and the number of reproducing females initially stocked in the mesocosms.

\section{Figure 2}

Relation entre la biomasse de gambusie (poids frais, g) à la fin de l'expérimentation et le nombre de génitrices initialement introduites dans les mésocosmes.

Numbers of mosquitofish collected varied from 26 (1 pair) to 301 (6 pairs) (Figure 3). The value of the regression coefficient between the number of pairs initially stocked and the number of mosquitofish recovered was $0.86(p<0.03)$. Nevertheless, this relationship appeared to be less strong than that between produced biomass and number of pairs. 


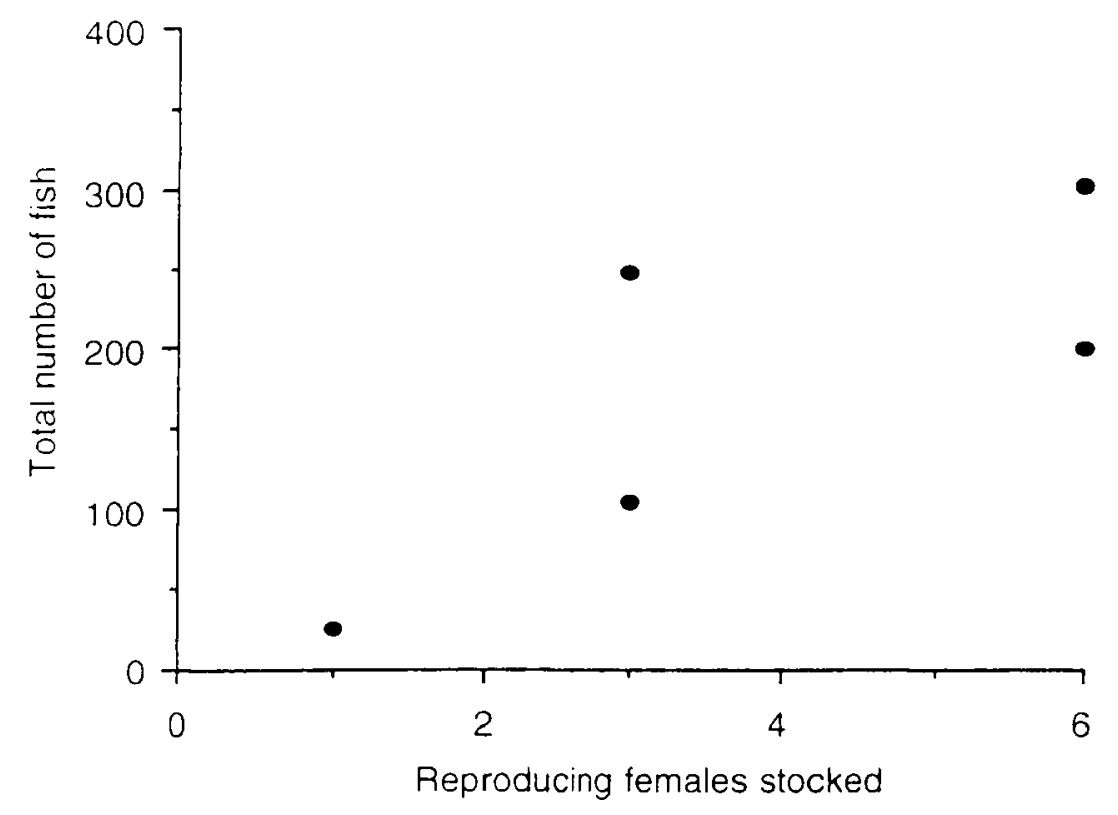

Figure 3

Relationship between the total number of fish collected at the end of the experiment and the number of reproducing females initially stocked in the mesocosms.

\section{Figure 3}

Relation entre le nombre d'individus récupérés en fin d'expérimentation et le nombre de génitrices initialement introduites dans les mésocosmes.

The number of mosquitofish collected and the produced biomass at the end of the experiment were statistically correlated $(p<0.05)$ (data not shown).

\section{Condition Index and sex-ratio}

The Condition Index (x 100) varied between mesocosms from $0.8 \pm 0.1$ (standard deviation) to $1.0 \pm 0.1$ in juveniles, from $0.7 \pm 0.1$ to $0.9 \pm 0.1$ in males, and from $0.8 \pm 0.1$ to $1.0 \pm 0.1$ in females. No relationship was found between the Condition Index and fish density at the end of the experiment (data not shown).

Sex-ratios calculated for each mesocosm are presented in Table I. Among mature fish sex-ratio was not statistically different of unity, except for one mesocosm (female dominated). Among juveniles sex-ratio deviated significantly from unity in two mesocosms (female dominated in the one, male dominated in the other). 


\section{Table I}

Number of male and female mosquitofish and sex-ratio among juveniles and adults collected at the end of the experiment.

\section{Tableau I}

Nombre de gambusies mâles et femelles et sex ratio parmi les juvéniles et les adultes récupérés en fin d'expérience.

\begin{tabular}{ccccccc}
\hline $\begin{array}{c}\text { Initial numbers } \\
\text { of individuals } \\
\text { per } \\
\text { mesocosm }\end{array}$ & Males & Females & $\begin{array}{c}\text { Juveniles } \\
\text { Sex-ratio } \\
(\mathrm{M}: \mathrm{F})\end{array}$ & Males & Females & $\begin{array}{c}\text { Adults } \\
\text { Sex-ratio } \\
\text { (M:F) }\end{array}$ \\
\hline $1 \mathrm{M}: 1 \mathrm{~F}$ & 12 & 2 & $6.0: 1^{\star}$ & 4 & 5 & $0.8: 1$ \\
$3 \mathrm{M}: 3 \mathrm{~F}$ & 73 & 55 & $1.3: 1$ & 23 & 31 & $0.7: 1$ \\
$3 \mathrm{M}: 3 \mathrm{~F}$ & 15 & 7 & $2.1: 1$ & 25 & 55 & $0.4: 1^{\star}$ \\
$6 \mathrm{M}: 6 \mathrm{~F}$ & 56 & 90 & $0.6: 1^{*}$ & 68 & 76 & $0.9: 1$ \\
$6 \mathrm{M}: 6 \mathrm{~F}$ & 14 & 16 & $0.9: 1$ & 77 & 87 & $0.9: 1$ \\
\hline
\end{tabular}

* statistically different from unity $(p<0.05)$

$M$ : male

$F$ : female

\section{DISCUSSION}

The reproductive activity of mosquitofish appears to be mainly governed by photoperiod and to a lesser extent by temperature (BROWN and FOX, 1966 ; DAVIS, 1978 ; MEDLEN, 1951). In temperate areas, reproductive activity is suppressed during winter (HUGHES, 1986) but can be restored when daylight exceeds $12 \mathrm{~h}$ (CECH et al., 1992 ; HAYNES, 1993). In our study, illumination was sufficient until the end of September. Besides, mosquitofish were preferably located in the upper part of the water column, in areas receiving direct sunlight with water temperature higher than in other areas. Consequently, in our mesocosms, illumination and thermal conditions were probably appropriate to sustain reproductive activity of mosquitofish up to the end of September. Accordingly, length-frequency distributions for both females and juveniles show several peaks of fish born in the mesocosms. The four clearly distinguishable peaks observed in the mesocosms stocked with 6 pairs as well as in one of the mesocosms stocked with 3 pairs are in agreement with a gestation period of about one month as described in the literature (KRUMHOLZ, 1948 ; VONDRACEK et al., 1988).

In the mesocosms, the structure of mosquitofish populations deduced from the length-frequency distribution analysis followed similar general patterns. Mesocosms similarly designed can therefore hold similar patterns of development of mosquitofish populations. Mortality could explain the reduced size of the groups corresponding to the oldest fish. In natural ecosystems, possible causes of mortality include insect predators, predatory fish and avian predators (BOTSFORD et al., 1987). In our mesocosms, only insect predators could have preyed on mosquitofish. Cannibalism has been reported in mosquitofish (KRUMHOLZ, 1948 ; WALTERS and LEGNER, 1979). In our mesocosms, however, the extensive development of macrophytes was likely to increase refuges from 
both cannibalism and insect predation. In a laboratory experiment, MEFFE (1992) reported that females of Gambusia affinis holbrooki attained sexual maturity after 64 and 28 days at 25 and $32^{\circ} \mathrm{C}$, respectively, while males were sexually mature after 1 month at both temperatures. Therefore, in our experiment, females and males born in July and August could have reproduced before the end of the reproductive season. Differences between mesocosms with respect to the contribution of these females to recruitment could explain, at least in part, the variations in the abundance of juvenile classes at the end of the experiment.

Habitat conditions play a major role in the development of mosquitofish populations. Mosquitofish typically inhabit small, shallow bodies of water often partially or heavily vegetated (MEFFE and SNELSON, 1989). The mesocosms used in the present study were fairly similar to typical mosquitofish habitats. In such small water bodies, fish species foraging for a restricted range of preys may have their trophic resources rapidly limited. In contrast, mosquitofish exhibit a broad food choice. Algae, zooplankton, insects, molluscs were found in stomach of mature mosquitofish from experimental ponds, and frequencies of occurrence indicated a density-dependent trend of food consumption (WALTERS and LEGNER, 1979). In our study, the Condition Index was found to be quite similar between the different mesocosms whereas population density varied of one order of magnitude (26 vs 301). Therefore, Condition Index did not reflect competition for trophic resources available in the mesocosms.

In the present study, all the individuals of the populations were eventually collected and the sex was determined in both mature (determined as fish $>20 \mathrm{~mm}$ ) and immature fish. The anal fin is sexually dimorphic in adult mosquitofish but not in juveniles in which sex determination must be performed through microscopic analysis of the gonads. In studies on the life history traits of mosquitofish, sex-ratios are usually calculated from samples of adults (HAYNES and CASHNER, 1995 ; VARGAS and DE SOSTOA, 1996). In all mesocosms except one, the sex-ratio was not significantly different from the unity for mature fish. This result contrasts with literature data that mainly report a female-biased sex-ratio in adults sampled in wild mosquitofish populations (HILDEBRAND, 1927 ; KRUMHOLZ, 1948 ; SNELSON, 1989 ; VARGAS and DE SOSTOA, 1996) although tremendous variations were noted throughout the year (HAYNES and CASHNER, 1995). Males have been suspected to suffer higher rate of mortality than females due to higher sensitivity to stressors and accelerated physiological aging (SNELSON, 1989). Nevertheless, further investigations would be necessary to investigate the representativity of sampling methods towards adults of both sexes in the field. In mosquitofish, the sex-ratio at birth is 1:1 (KRUMHOLZ, 1948). In the present study, the sex-ratio of juveniles was proved to be significantly different from unity in 2 mesocosms among 5 , suggesting that biased sex-ratio may appear before the adult stage.

Many ecotoxicological studies have paid a particular attention to the impact of chemicals on reproduction in fish. Numerous studies carried out in controlled conditions showed that the fecundity and/or fertility can be affected by various compounds (DONALDSON, 1990). In the field, the role of chemicals in the decline of fish populations has been suggested (MAC and EDSALL, 1991). Direct links between changes in fecundity/fertility and disturbances of population dynamics have been often hypothesized but only a few experimental studies have dealt with such a topic. As a prerequisite to investigations on the impact of chemicals at the population level, development of fish population must be reproducible in experimental systems. Furthermore, ecotoxicological data are more relevant in experimental conditions that reproduce realistic biological processes. In our study, mesocosms were stocked with different numbers of reproducing pairs (1,3 and 6) of adult mosquitofish, thus simulating different fecundity/fertility potentials. At the end of the experiment, the produced biomass and number of individuals were shown to be both correlated with stocking level. This suggests that in our 
experimental conditions environmental factors did not induce stochastic variations in the development of mosquitofish populations, and that population was primarily determined by the fecundity/fertility potential initially introduced in the mesocosms as the number of reproducing adults. Consequently, the direct alteration of fecundity/fertility of adult mosquitofish by chemicals might be characterized experimentally at the population level.

Due to the variety of modes of action of chemicals, ecotoxicological studies in mesocosms usually investigate a broad spectrum of biological indicators (CAQUET et al., 1996 ; HILL et al., 1994). Accordingly, studies on mosquitofish should not preclude studies on other indicating species. In 15- $\mathrm{m}^{3}$ outdoor mesocosms stocked with 35 immature and 4 adult mosquitofish, GIDDINGS et al. (1984) were able to monitor the impact of chronic exposure to coal-derived oil on fish populations as well as on physico-chemical parameters, bacteria, primary producers, zooplankton, and insects for one year. In contrast, some studies pointed out a strong influence of mosquitofish on ecosystems structure and functioning. In little pools ( $2 \mathrm{~m}$ diameter, $30 \mathrm{~cm}$ water depth) stocked with 50 mosquitofish, phytoplankton was shown to proliferate as a consequence of a decrease in zooplankton density, and insects were eliminated after one year (HURLBERT et al., 1972). Similar trends were observed in larger mesocosms (4 m $\times 6 \mathrm{~m}, 50 \mathrm{~cm}$ water depth) stocked with either 50 or 450 mosquitofish (HURLBERT and MULLA, 1981). Significant impact of mosquitofish on zooplankton taxa was also noticed in experimental ponds ( $4 \mathrm{~m} \times 7 \mathrm{~m}, 36 \mathrm{~cm}$ water depth) stocked with 10 mature males and 15 mature females. Unfortunately in these studies, no data were available concerning the size of mosquitofish populations. In the mesocosms used in the present study, abundance of some taxa of emerging insects was reduced when compared to similar mesocosms without mosquitofish (data not shown). Further studies are thus needed to investigate the effects of stocking rate of mosquitofish on other compartments of such ecosystems.

\section{CONCLUSION}

The development of mosquitofish populations was obtained in lentic mesocosms designed in the perspective of ecotoxicological studies. The results suggest non-stochastic development of mosquitofish populations in these experimental ecosystems and argue for the use of mosquitofish for the experimental studies of the impact of chemicals on fish populations.

\section{ACKNOWLEDGEMENTS}

This study was supported in part by the GIP Hydrosystèmes (Programme Evaluation de l'état de santé écologique des hydrosystèmes par l'utilisation de variables biologiques). The authors thank $L$. Lagadic for valuable discussions and comments, J.F. Baroiller for helpful advice on sex determination of juveniles, M. Heydorff, P.M. Lucas and $C$. Tessier for technical assistance, and A. Jumel for information on emerging insects.

\section{REFERENCES}

BOTSFORD L.W., VONDRACEK B., WAINWRIGHT T.C., LINDEN A.L., KOPE R.G., REED D.E., CECH J.J.Jr., 1987. Population development of the mosquitofish, Gambusia affinis, in rice field. Environ. Biol. Fishes, 20, 143-154.

BROWN C.J.D., FOX A.C., 1966. Mosquitofish (Gambusia affinis) in a Montana pond. Copeia, 1966, 614-616. 
CAQUET T., LAGADIC L., JONOT O., BATURO W., KILANDA M., SIMON P., LE BRAS S., ECHAUBARD M., RAMADE F., 1996. Outdoor experimental ponds (mesocosms) designed for long-term ecotoxicological studies. Ecotox. Environ. Safety, 34, 125-133.

CECH J.J.Jr., SCHWAB R.G., COLES W.C., BRIDGES B.B., 1992. Mosquitofish reproduction effects of photoperiod and nutrition. Aquaculture, 101, 361-369.

CONSTANTZ G.D., 1989. Reproductive biology of poeciliid fishes. In MEFFE G.K., SNELSON F.F.Jr., eds, Ecology and evolution of livebearing fishes (Poeciliidae), 33-50, Prentice-Hall, Inc., Englewood Cliffs, New Jersey.

DAVIS J.R., 1978. Reproductive seasons in Gambusia affinis and Gambusia geiseri (Osteichthys : Poeciliidae) from southcentral Texas. Texas J. Sci., 30, 97-99.

DONALDSON E.M., 1990. Reproductive indices as measures of the effects of environmental stressors in fish. Am. Fish. Soc. Symposium, 8, 109-122.

DRYSDALE D.T., BORTONE S.A., 1989. Laboratory induction of intersexuality in the mosquitofish Gambusia affinis using paper mill effluent. Bull. Environ. Contam. Toxicol., 43, 611-617.

GIDDINGS J.M., FRANCO P.J., CUSHMAN R.M., HOOK L.A., SOUTHWORTH G.R., STEWART A.J., 1984. Effects of chronic exposure to coal-derived oil on freshwater ecosystems : II. Experimental ponds. Environ. Toxicol. Chem., 3, 465-488.

GUERRERO R.D., SHELTON W.L., 1974. An aceto-carmine squash method for sexing juveniles fishes. Prog. Fish Cult., 36, 56.

HAYNES J.L., 1993. Annual re-establishment of mosquitofish populations in Nebraska. Copeia, 1993, 233-235.

HAYNES J.L., CASHNER R.C., 1995. Life history and population dynamics of the western mosquitofish : A comparison of natural and introduced populations. J. Fish Biol., 46, 1026-1041.

HILDEBRAND S.F., 1927. Sex ratio in Gambusia. Biol. Bull., 53, 390-404.

HILL I.R., RUNNALLS J.K., KENNEDY J.H., EKONIAK P., 1994. Lambda-cyhalothrin : A mesocosm study of its effects on aquatic organisms. In HILL I.R., HEIMBACH I.R., LEEUWANGH P., MATTHIESSEN P., eds, Aquatic mesocosm studies in ecological risk assessment, 403-467, SETAC Special Publications Series, Lewis Publishers, Boca Raton, Florida.

HOWELL W.M., BLACK D.A., BORTONE S.A., 1980. Abnormal expression of secondary sex characters in a population of mosquitofish, Gambusia affinis holbrooki : Evidence for environmentally-induced masculinization. Copeia, 1980, 676-681.

HUGHES A.L., 1986. Seasonal changes in sexual receptivity of female mosquitofish Gambusia affinis. Biol. Behav., 11, 3-15.

HUNSINGER R.N., BYRAN B.A., HOWELL W.M., 1988. Unchanged gonadal morphology in mosquitofish exposed to degraded plant sterols. J. Fish Biol., 32, 795-796.

HURLBERT S.H.J., ZEDLER J., FAIRBANKS D., 1972. Ecosystem alteration by mosquitofish (Gambusia affinis) predation. Science, 175, 639-641.

HURLBERT S.H., MULLA M.S., 1981. Impacts of mosquitofish (Gambusia affinis) predation on plankton communities. Hydrobiologia, 83, 125-151.

JOHNSON C.R., 1976. Observations on growth, breeding, and fry survival of Gambusia affinis affinis (Pisces : Poeciliidae) under artificial rearing conditions. Proc. Pap. Annu. Conf. California Mosq. Vector Control Assoc., 44, 48-51.

KENNEDY J.H., JOHNSON Z.B., JOHNSON P.C., 1994. Sampling and analysis strategy for biological effects in freshwater field. In HILL I.R., HEIMBACH I.R., LEEUWANGH P., MATTHIESSEN P., eds, Freshwater field tests for hazard assessment of chemicals, 159-182, CRC press, Inc., Boca Raton, Florida. 
KRUMHOLZ L.A., 1948. Reproduction in the western mosquitofish Gambusia affinis affinis (Baird \& Girard) and its use in mosquito control. Ecol. Monogr., 18, 1-43.

LLOYD L.N., TOMASOV J.F., 1985. Taxonomic status of the mosquitofish, Gambusia affinis (Poeciliidae), in Australia. Aust. J. Mar. Freshw. Res., 36, 447-451.

MAC M.J., EDSALL C.C., 1991. Environmental contaminants and the reproductive success of lake trout in the Great Lakes : An epidemiological approach. J. Toxicol. Environ. Health, 33, 375-394.

MCCARTHY J.F., SHUGART L.R., (eds), 1990. Biomarkers of environmental contamination, Lewis Publishers, Boca Raton, Florida, $457 \mathrm{p}$.

MEDLEN A.B., 1951. Preliminary observations on the effects of temperature and light upon reproduction in Gambusia affinis. Copeia, 1951, 148-152.

MEFFE G.K., SNELSON F.F., (eds), 1989. Ecology and evolution of livebearing fishes (Poeciliidae), Prentice-Hall, Inc., Englewood Cliffs, New Jersey, 453 p.

MEFFE G.K., 1992. Plasticity of life history characters in eastern mosquitofish (Gambusia holbrooki : Poeciliidae) in response to thermal stress. Copeia, 1992, 94-102.

MORRIS R.G., KENNEDY J.H., JOHNSON P.C., HAMBLETON F.E., 1994. Pyrethroid insecticide effects on bluegill sunfish in microcosms and mesocosms and bluegill impact on microcosm fauna. In HILL I.R., HEIMBACH I.R., LEEUWANGH P., MATTHIESSEN P., eds, Aquatic mesocosm studies in ecological risk assessment, 373-395, SETAC Special Publications Series, Lewis Publishers, Boca Raton, Florida.

MULLA M.S., MAJORI G., ARATA A.A., 1979. Impact of biological and chemical mosquito control agents on nontarget biota in aquatic ecosystems. Residue Rev., 71, 121173.

MULVEY M., NEWMAN M.C., CHAZAL A., KEKLAK M.M., HEAGLER M.G., HALES L.S.Jr., 1995. Genetic and demographic responses of mosquitofish (Gambusia holbrooki Girard, 1859) populations stressed by mercury. Environ. Toxicol. Chem., 14, 1411-1418.

REZNICK D.N., MILES D.B., 1989. A review of life history patterns in poeciliid fishes. In MEFFE G.K., SNELSON F.F.Jr., eds, Ecology and evolution of livebearing fishes (Poeciliidae), 149-161, Prentice-Hall, Inc., Englewood Cliffs, New Jersey.

SHAW J.L., MAUND S.J., MARSHALL S.J., HILL I.R., 1995. Fathead minnow (Pimephales promelas Rafinesque) reproduction in outdoor microcosms : An assessment of the ecological effects of fish density. Environ. Toxicol. Chem., 14, 1763-1772.

SNELSON F.F., 1989. An ecological overview of poeciliid fishes. In MEFFE G.K., SNELSON F.F.Jr., eds, Ecology and evolution of livebearing fishes (Poeciliidae), 13-31, Prentice-Hall, Inc., Englewood Cliffs, New Jersey.

VARGAS M.J., DE SOSTOA A., 1996. Life history of Gambusia holbrooki (Pisces, Poeciliidae) in the Ebro delta (NE Iberian Peninsula). Hydrobiologia, 341, 215-224.

VONDRACEK B., WURTSBAUGH W.A., CECH J.J.Jr., 1988. Growth and reproduction of the mosquitofish Gambusia affinis in relation to temperature and ration level : consequences for life history. Environ. Biol. Fishes, 21, 45-58.

WALTERS L.L., LEGNER E.F., 1979. Impact of the desert pupfish, Cyprinodon macularius and Gambusia affinis affinis on fauna in pond ecosystems. Hilgardia, 48, 1-18.

YAN H.Y, 1986. Report of a naturally masculinized female of the Clear Creek gambusia, Gambusia heterochir Hubbs. J. Fish Biol., 28, 55-59. 